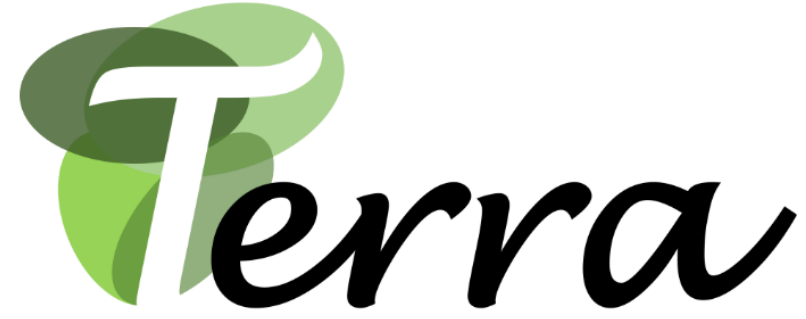

Revista de Desarrollo Local

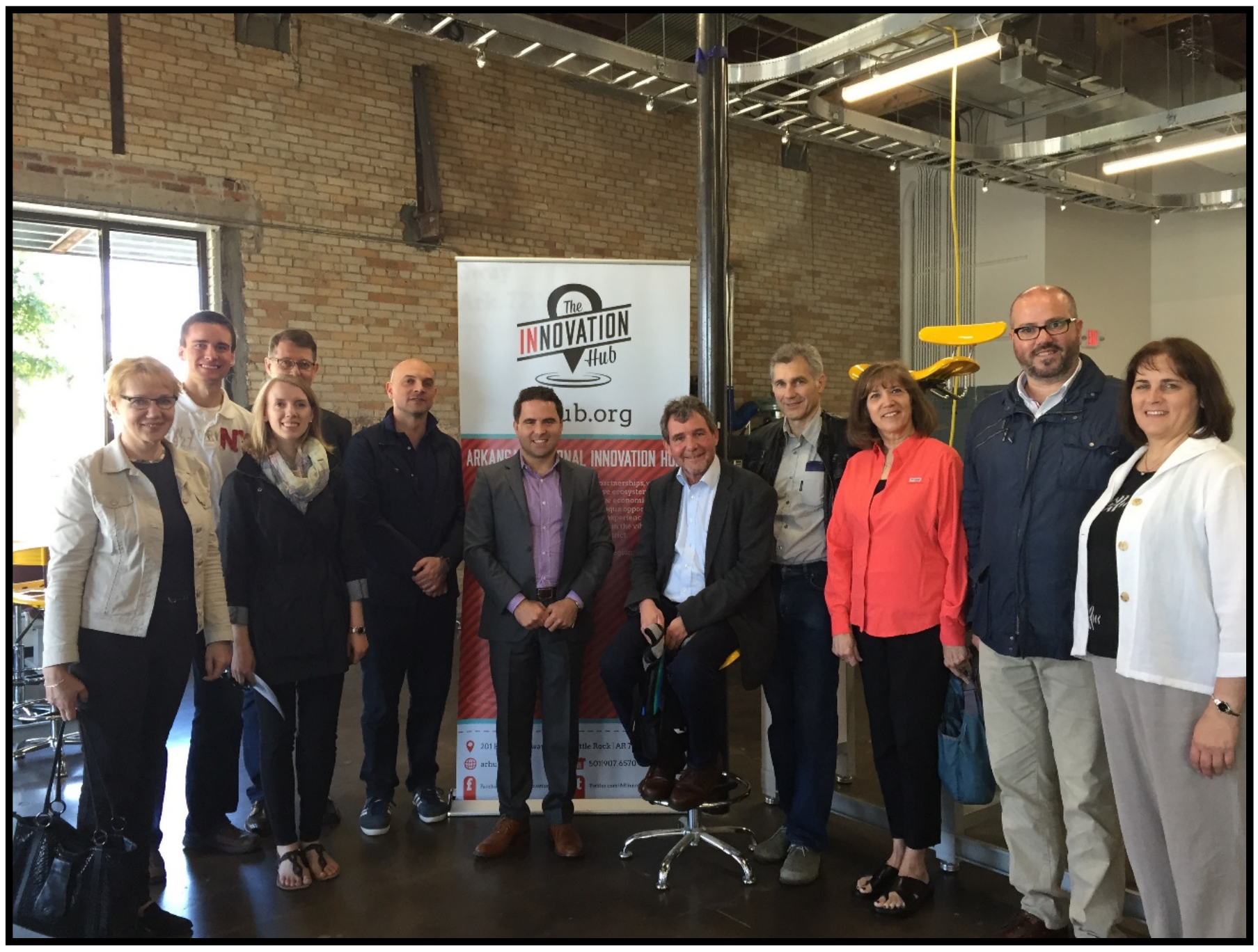

- Homenaje a Joan Noguera Tur -

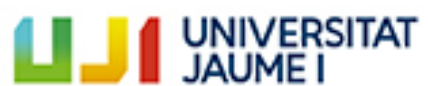

Institut Interuniversitari de Desenvolupament Local

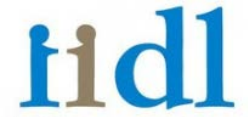

I N S T I T INIERUNIVERSIIARI DE DESENVOUUPAMENT LOCAL

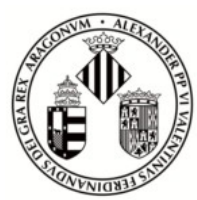

VNIVERSITAT

[B ValènCIA 
TERRA. Revista de Desarrollo Local e-ISSN: 2386-9968

Número 8 (2021), 310-331

DOI 10.7203/terra.8.20367

IIDL - Instituto Interuniversitario de Desarrollo Local

\title{
Enhancing local development through trans- regional cooperation: Lessons from long-term practice of the LEADER concept
}

\author{
Thomas Dax \\ Federal Institute of Agricultural Economics, Rural and Mountain Research (BAB) \\ (Vienna, Austria) \\ Thomas.Dax@bab.gv.at \\ https://orcid.org/0000-0002-0281-0926
}

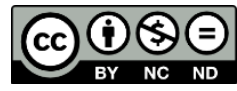

Esta obra se distribuye con la licencia Creative Commons

Reconocimiento-NoComercial-SinObraDerivada 4.0 Internacional 


\title{
SECCIÓN ARTÍCULOS
}

\section{Potenciar el desarrollo local mediante la cooperación transregional: lecciones prácticas a partir de LEADER}

Resumen: Durante mucho tiempo se consideró que el desarrollo local combinaba múltiples esfuerzos para fortalecer las zonas desfavorecidas o remotas, con riesgo de periferización o incluso de marginación. A partir de los años ochenta, la concienciación sobre el potencial endógeno y los servicios rurales permitió centrarse más en la capacidad de acción y cambio local específico de cada territorio. Este cambio en la política regional promovió el apoyo a los territorios rurales, centrándose especialmente en zonas de geografía específica, como montañas, islas y otros lugares "desfavorecidos". Calificado como "desarrollo regional endógeno", este planteamiento queda plasmado en el principal programa de desarrollo local de la UE, el programa LEADER, disponible desde 1991. Aunque se centró en establecer incentivos para el desarrollo en contextos rurales, el rendimiento de las regiones rurales, sin embargo, se estancó desde entonces. Este documento concibe el proceso de desarrollo local y la influencia de la cooperación transregional como los motores decisivos e interrelacionados de todo el proceso. Los efectos limitados podrían estar relacionados con la dependencia del camino, el bloqueo institucional y el escaso reconocimiento y énfasis en el papel crucial de la innovación social, lo que ahoga la necesaria adaptación de las políticas. Sin embargo, la orientación hacia la combinación de la experiencia y la contribución de los sistemas de conocimiento externos, con la singularidad y los activos locales, son aspectos que podrían contribuir de manera decisiva a los incentivos y cambios sociales tan deseados.

Palabras clave: Desarrollo rural, LEADER, innovación social, cooperación transnacional, desarrollo local dirigido por la comunidad.

Enhancing local development through trans-regional cooperation: Lessons from long-term practice of the LEADER concept

\begin{abstract}
For long, local development was seen as combining multiple efforts for strengthening areas that were either disadvantaged or remote, at-risk of peripheralization or even of marginalization. Since the 1980s an emerging awareness of endogenous potential and rural amenities enabled a stronger focus on the areaspecific capability for local action and change. This shift in regional policy instigated support for remote places, focusing particularly on areas of specific geographies, like mountains, islands and other places of "disadvantage". Referred to as "endogenous regional development" that approach is epitomized by the main local development scheme of the EU, the LEADER programme which was available since 1991. While it focused on setting development incentives in rural contexts, the performance of rural regions, nevertheless, stagnated since then. This paper conceives the local development process and the influence by trans-regional cooperation as the decisive, inter-related drivers. Limited effects might be linked to path dependency, institutional lock-in and little recognition and emphasis on the crucial role of social innovation, stifling required policy adaptation. Yet, particularly the orientation on combining the experience and contribution of external knowledge systems with uniqueness and local assets might contribute decisively to the long-desired incentives and social changes.
\end{abstract}

Key words: Rural development, LEADER, social innovation, trans-national cooperation, community-led local development.

Recibido: 03 de diciembre de 2020

Devuelto para revisión: 29 de abril de 2021

Aceptado: 27 de mayo de 2021

Referencia / Citation:

Dax, T. (2021). Enhancing local development through trans-regional cooperation: Lessons from long-term practice of the LEADER concept. TERRA. Revista de Desarrollo Local, (8), 310-331. DOI 10.7203/terra.8.20367 


\section{INTRODUCTION}

In recent years, a reversal towards local issues and policy solutions has gained momentum, following the rise of inter-related economic, political, ecological and health crises (Donald and Gray, 2019). However, the concern with local development reflects a long-term commitment of practitioners working in various spatial contexts. The term itself is used in different spatial contexts, either urban or rural, indicating the crucial influence of specific contextual aspects for shaping socio-economic development processes and the need to address the "local" specificities in any development action (Pike et al., 2006). Realizing its wide societal impact this perspective was integrated.

into high-level policy discourse, for example in the OECD Programme on Local Economic and Employment Development (LEED) ${ }^{1}$, community development concepts supported by $\mathrm{FAO}^{2}$, Community-Driven Development (CDD) programs by the World Bank $^{3}$, the ILO's work on Local Development for Decent Work ${ }^{4}$, and many more largescale development programmes.

There is ample evidence of the need to address the specific spatial, institutional, social, cultural, economic and environmental contexts in order to address challenges and opportunities of rural regions appropriately. This approach is underpinned increasingly in discussion on remote areas, less-favoured and mountain regions where differences occur at a very fine spatial level (De Toni et al., 2020), requiring specific local-based answers in spatial strategies and development action (Dax, 2015).

The almost unquestioned support for unrestricted trade and global interdependence implied fundamental changes in the economic activities and social organization of all parts of the world, adding to the need for place-based policies. While place-specificity was widely acknowledged as an important driver for regional development, the perception of "globalization" affecting living conditions and economies throughout our societies was presented and accepted as unavoidable. Against this backdrop the emerging concept of local development was acknowledged to dispose of two different perspectives (Bryden, 2010). The first realizes local development in opposition to growing state power, including the tendency of globalization as addressed above and growing corporate power. The second and more recent definition is linked to public management and particularly based on the increasing "need to improve the effectiveness and efficiency of public policies organized from centres of government" (Bryden, 2010, p. 240). While for a long time the management approach was predominant and influential to the application and shaping of programmes for rural development support (Stöhr, 1984), more recently a rising need for emphasizing community development, participatory approaches and acknowledging power relations is advocated also within programme implementation (Lowe et al., 2019).

\footnotetext{
${ }^{1}$ The OECD LEED programme's mission is to contribute to the creation of more and better quality jobs through more effective policy implementation, innovative practices, stronger capacities and integrated strategies at the local level. LEED draws on a comparative analysis of experience from the five continents in fostering economic growth, employment and inclusion. Many findings and recommendations of the wide-ranging analysis are relevant for rural regions and applicable to the project's discussion of local development (http://www.oecd.org/local-forum/).

${ }^{2}$ http://www.fao.org/europe/news/detail-news/en/c/882204/

${ }^{3} \mathrm{https}: / / \mathrm{www}$.worldbank.org/en/topic/communitydrivendevelopment

${ }^{4}$ https://www.ilo.org/asia/decentwork/adwd/WCMS_098229/lang--en/index.htm
} 
The two aspects of "localizing" the development agenda have been particularly relevant for assessment of local action which has flourished in the shadow of large-scale regional growth, innovation and cohesion-oriented policies. In Europe, many years of experience with the implementation of LEADER have shown that the original concerns for achieving effective changes through implementing place-sensitive projects in rural, peripheral regions have been refuted. Over the past three decades, thousands of Local Action Groups (LAGs) in the EU with a wide variety of different ideas, projects and thematic orientations have shown that there is an abundance of inspiring approaches for successful local development trajectories. Over this long period, the contribution of LEADER to the spatial development of rural areas has been recognized and discussed very intensively by those involved in the programme conceptualization and implementation, the local population, international experts and decision-makers (Champetier, 2017; Lukesch, 2018). As a consequence, this has also led to a change in the conception of rural development measures and their integration into EU funding programs. The idea of maximizing the impact through local initiatives has been reflected in the expansion of the original pilot action into a standard "program" that is applied in all rural areas. In addition, the corresponding measures were integrated into the rural development program (from 2000) and later, from the funding period 2007-2013 onwards, all measures of the rural development program (RDP) were recognized as possible activities of LEADER. This formal integration into the framework of RDPs was supported by the official term of "mainstreaming" of LEADER, i.e. the application of the LEADER approach to all measures of the rural development program. Broadening the scope for action in a targeted manner should strengthen the quantitative impact of LEADER on economic development in the regions (Lukesch et al., 2004).

Such a rise in the recognition of the relevance of the LEADER approach for the implementation of rural development in general was only possible due the conviction of many observers and practitioners that such local action presented an appropriate answer to the rural challenges and that it was the best way to make European policy visible for rural citizens. While this positive assessment and the underlying principles of LEADER were unchallenged, implementation faced a number of detailed obstacles. All over the consecutive LEADER programme periods trans-national cooperation was presented as the particular feature for extending learning experiences which would enhance local assets through increased cross-fertilization of ideas, concepts and approaches (Kasabov, 2014). However, the potential signposted in conceptualizing was hardly realized in programming and implementation reality due to overwhelming constraints in institutional settings and slow advancement of local capacity (Pylkkänen et al., 2020). Studies aiming to take account of the long-term effects and the innovative content of LEADER did not just point to positive local outcomes, but highlighted also shortcomings in achieving the desired effects with regard to innovation, cross-sectoral integration, involvement and strategic outline (Navarro et al., 2015; Dax et al., 2016). A further challenge, which is often disregarded, is the intricate aspects of institutional changes in local organizations, the development of cooperation structures at this level and process design (Kull, 2014; Granberg et al., 2015; ENRD, 2018; Cejudo and Navarro, 2020). It was argued that the inclusion of all stakeholder groups and interest groups (Lowe et al., 1999) should lead to far-reaching learning processes in the course of local development processes.

The wide-ranging orientation of the concept underpins the crucial aspect of social processes within the framework of LEADER conceptualization and implementation (Dargan and Shucksmith, 2008). In this context, innovation is not seen primarily in the form of product innovation, but to a decisive extent as "social innovation". According to 
Zapf, this search for solutions to social problems is defined as follows: "Social innovations are new ways of achieving goals, especially new forms of organization, new regulations, new lifestyles that change the direction of social change, solve problems better than previous practices and are therefore worth imitating and institutionalizing" (Zapf, 1994, p. 33; translation by author).

The focus on social innovation and the main drivers influencing altered views and impacting on change options (Green, 2016) for local socio-economic development is hence the core interest in this article. It will deal particularly with the nagging question how contributions by external experts and trans-regional cooperation might enhance local knowledge systems and harness unique assets of rural regions. The outline will address the respective interrelationships and underscore the specific role of trans-regional cooperation in instigating changes and fruitful place-sensitive action in the long-run. As for LEADER assessment studies their crucial place is either taken for granted or inherent obstacles tend to be neglected, excuse is often sought on recurring to their limited measurability and long-term objectives (Dax et al., 2014). However, these difficult to measure aspects of LAG cooperation with external partners might be conceived as crucial success factors of LEADER for achieving sustainable impact in the long run, which transcend immediately visible quantitative impacts.

In linking local and trans-local objectives, this perception follows recent conceptual turns emphasizing Smart Specialization Strategies (Da Rosa Pires et al., 2014; Torre et al., 2020) and the concept of Smart Villages (Visvizi et al., 2019). In addressing recently emerging concepts the mutual influence of LEADER and these ideas should be discussed in nurturing strategies towards intensifying Community-Led Local Development (CLLD) approaches. These concepts prove particularly timely in dealing with increased challenges and changes in spatial mobility due to COVID-19 pandemic and deliberations on future strategies for LEADER 2023-27.

This paper will hence present after a brief methodological section an analysis of the LEADER concept focusing on its endogenous assets before turning to an assessment of the practice of trans-regional exchange and the obstacles to emphasize this potential in regional operation. Concluding from failures observed in various contexts, the need to embrace diversity and social innovation as crucial triggers of local development will be explored in the discussion section. The conclusion will underline the need for considering increasingly community development, spatial interrelations and search for alternative pathways of LEADER encompassing its original comprehensive remit for economic and ecologic adaptation and social change in rural regions.

\section{METHODOLOGICAL APPROACH}

As the paper aims at addressing the specific interrelationship between local assets and action put forward by the LEADER concept and the potential of trans-regional exchange it builds on respective studies carried out in various EU Member States to assess achievements of trans-regional and trans-national action. Respective cooperation within countries or across country borders in principle show similar objectives, but might be linked to different types of obstacles. In particular, challenges increase for trans-national cooperation due to different institutional frameworks, and ensuing variation in governance concepts and understanding, socio-cultural variation and heritage, and often different languages. The analysis for the paper therefore referred to a comprehensive 
literature review on LEADER conceptualization and implementation, in general, assessment studies (at national and European level), and particularly trans-national instruments used in LEADER. To some extent, assessment available is particularly focused on good practice (Dax and Kah, 2017; Fortunato and Zumpano, 2018; LINC, 2019; Navarro-Valverde et al., 2020).

The analysis of ENRD (2011) to address added value of trans-national cooperation was used as framework to assess the various dimensions of added valued (hard and soft value) resulting from the analysed cooperation initiatives. As case examples these are not representative of policy implementation in quantitative terms but aim at including the most relevant aspects of cooperation.

As the exposure to alternative policy concepts through those cooperation processes animate self-reflection and reassessment of the own positions and approaches, changes in viewing the whole framework of local action are nurtured. Social innovation is explored as an inherently interlinked aspect to trans-national cooperation and relevant analysis on this aspect are a supplementary source for assessing the respective development discourse. Looking back on the long-term of LEADER implementation these two general influences are assessed as reflections of "external" influences on local actors and institutional developments. Respective studies indicating the need to assess also the qualitative nature of assessing local action are taken up and discussed with regard to their relevance to influence by trans-national experiences. It should be underpinned that a critical reflection of existing (local, regional, national) views might be useful for considering new options, realizing new assets and engaging in local action with inclusive and just approaches (Shucksmith et al., 2020). In this regard it seems crucial to reveal through a small number of case studies of trans-national cooperation the potential and challenges of such collaboration activities, and the relevance for the overall conceptual perspective of the LEADER/CLLD programme.

\section{ENDOGENOUS DEVELOPMENT AS RESPONSE TO CONCENTRATION FORCES}

At its origin, the LEADER program was designed as a pan-European activity for smallscale development of rural areas. Starting in the early 1990s as an experimental program it represented one of a series of "Community Initiatives" of the EU to tackle severe social and spatial problems. Due to the positive response and engagement of local actors it soon embraced significant expectations for rural initiatives and was perceived as "engine" for enhancing local strategies and rural change. Gradually, the scope of the application of the program was expanded until all rural regions and, later, all instruments of the Rural Development Programs were comprised. LEADER has thus evolved from promoting "endogenous regional development" to a widely hailed model of rural policy that is exemplary for rural development (Kull, 2014).

Several preconditions were fundamental to this beneficial implementation process. The simple and attractive program structure, oriented at local development needs, provided an evident and promising framework for political decision-makers and local actors as well. Built on an inter-related, comprehensive coverage of seven preconditions, effectiveness of the approach was demanded from participants, and was expected and observed in emerging innovative action. These 'LEADER principles' in general comprise the following aspects (EC, 2006): (i) Area-based local development strategies; (ii) Bottom- 
up elaboration and implementation of strategies; (iii) Local public-private partnerships: local action groups; (iv) Integrated and multisectoral actions; (v) Innovation; (vi) Cooperation; (vii) Networking. In addition to being anchored in a small-scale area, the LEADER concept emphasized local participation, linking activities between sectors and institutions, and following ideas of policy devolution, the local action groups (LAG) are responsible for designing and realizing innovative projects. In the funding period 20142020, this policy measure was expanded to include the Structural Funds (regional funds, social funds and fisheries funds) in addition to the EAFRD (European Fund for Rural Development) to enable so-called "Community-Led Local Development" (CLLD) programs. There are now over 3,300 LAGs active in the EU, with 788 LAGs making use of various combinations of multi-fund support applying the CLLD approach (Servillo and De Bruijn, 2018). It has thus been possible to see the realities of the rural regions to a much greater extent in terms of their strengths and their local development opportunities.

Over this long time of applying the LEADER approach, the orientation and priorities shifted in numerous ways. While application is primarily geared towards the local level in the design and conception of development strategies, it comprised from the beginning the objective to enhance and build on trans-regional and trans-national interaction as well. This conceptual wider scope was reflected in the term of "neo-endogenous approach" (Ray, 2006; Cejudo and Navarro, 2020), a conceptual elaboration that will be explored in the next section. Here, the drivers for local small-scale activities are in the center of our interest. Martin et al. (2015, p. 144) "recognise that regional specific effects make a very significant contribution to the ability of a region to resist and respond to economic shocks in a way that builds their future economic momentum. These regional specific effects can take a number of forms (...) and each provides a rich and diverse array of possible opportunities for policy intervention". We can argue that local development policies don't differ so much in the challenges they face from persistent demands for place-sensitive action and policy support in these areas. The numerous aspects highlighted in Figure 1 demonstrate the high complexity of local development processes and their contribution to local development and resilience. Those aspects that are particularly important in the LEADER implementation are highlighted in the illustration (see red font color). It is crucial that agency and local decision-making is the driving force for many of these. But the different spheres and interlinkages also address the complex nature of local development processes. It builds on the heritage and future visions, diversity of perceptions, alternative designs, trust and social cohesion, small and large-scale action, and linkages between sectors and spaces, thus encompassing the whole range of LEADER principles.

The orientation towards a more crisis-resistant implementation of local development funding is an urgent political task, especially in view of the COVID-19 pandemic since 2020. Local and regional adaptation processes must therefore take place in many fields, as shown in Figure 1: This concerns the design of the basic corporate structures and organizations, labor market conditions, the organization of banking and finance, the institutional framework and governance rules. Local and supra-regional influences must be considered in a balanced way (Katona-Kovács et al., 2011). The link between local politics and decision-making with regional (federal state level), national politics and global economic structures must therefore not be disregarded in designing local decisions (Celata and Coletti, 2015).

The high level of "trust" required for an effective local development is dependent on a well-developed understanding and involvement of local interest groups. Despite the longterm funding of peripheral regions, hardly any lasting effect to balance accessibility and 
life chances, or fundamental changes in the spatial effects could be achieved. As Harrison et al. (2020) show a missing or even misleading theoretical conception of regional development, which still focuses on competitiveness of large urban agglomerations and does not meet the challenges of peripheral rural regions, is also responsible for this. The problem that these authors discern in local and regional development policy is "that much of the theory is geared towards large urban agglomerations in the global north as nodes of innovation and competitive advantage, which links (all) territories to the global value chains" (Harrison et al., 2020, p. 134). Following this quote, it is central to consider the social and local conditions in the peripheral rural areas more closely in the theory of regional research in order to be able to design promising concepts and not to devalue these areas from the outset as hardly surmountable "problem areas".

Figure 1: Drivers of local and regional development and adaptation

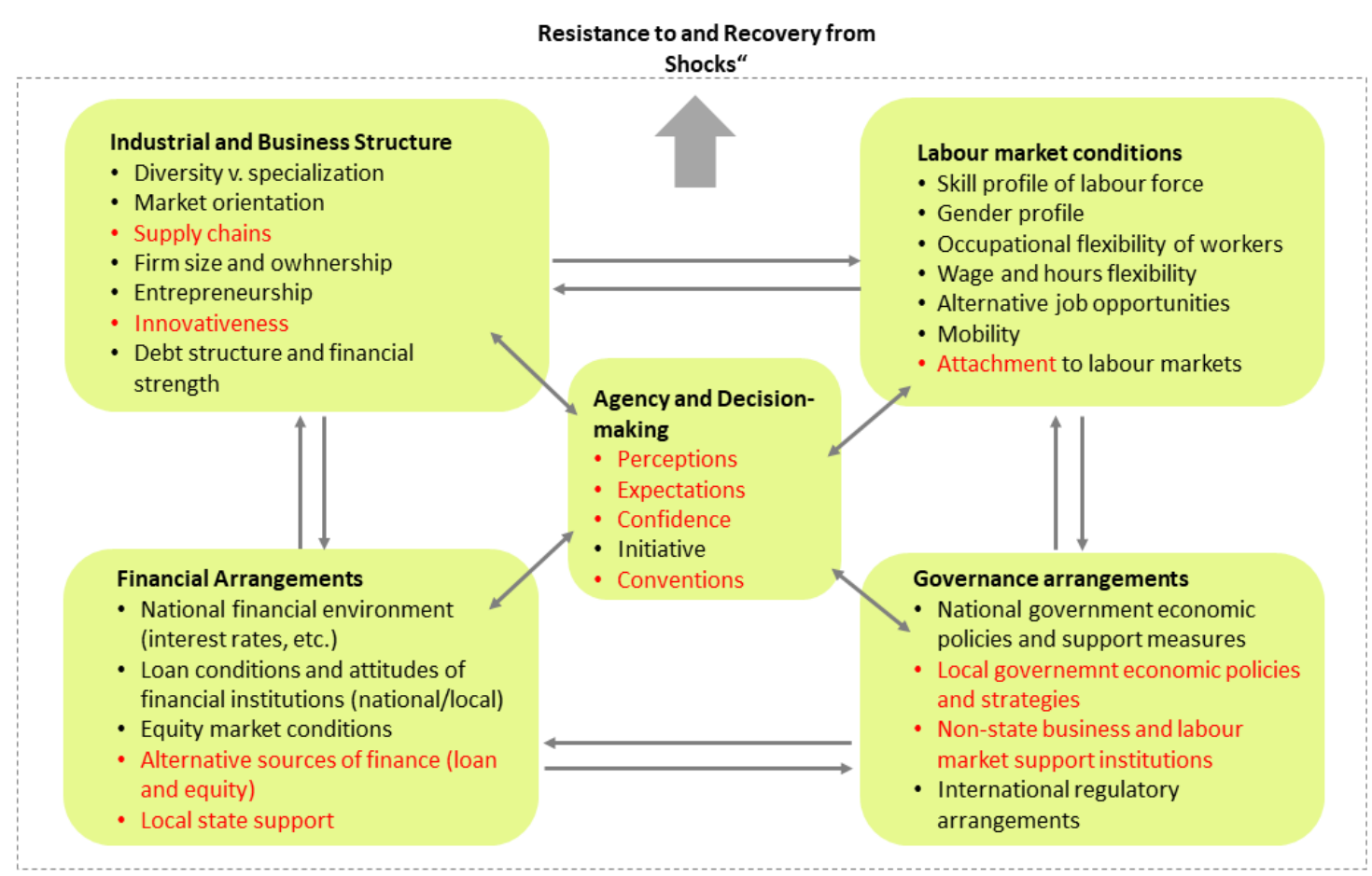

Source: Martin et al., 2015, p. 145.

\section{NETWORKING AND TRANS-REGIONAL EXCHANGE}

The concentration on the small-scale level and the special attention that LEADER devotes to local conditions and challenges are only one side of the coin. The concept is based in particular on the premise that the networking of European actors in rural areas contributes to a fruitful exchange and to increasing the capacity of the rural actors and attractiveness of rural regions. As a network activity, LEADER intends to nurture the exchange of ideas, involved local actors, approaches and development networks and visions between the rural regions of Europe. This task is carried out by the European Network for Rural Development (ENRD) and national networks in all EU-countries.

The action line, foreseen from the beginning of LEADER for trans-national cooperation, takes account of the high degree of external dependency and susceptibility to "shocks" of 
all kinds. Much of the learning process resulting from such activities fosters innovative design process, reflecting the demand for "modernization" of rural structures (OECD, 2014) and participation in "globalization" networks. However, often insertion in such "efficient" large-scale structures are associated with drastic changes, which meet massive resistance from local decision-makers, who might lose autonomy and influence spheres. Local adaptability is therefore a primary policy objective for forward-looking regional and rural policies geared towards innovation, facing tensions with external influences, not-adapted policy objectives and value systems, and limitations by large-scale structural paradigms.

Nevertheless, from the observation of the emergence of new ideas and activities it becomes clear that innovation is very much initiated by dealing with other cultures, perspectives and approaches to solutions. This perception was decisive at the origin of the conceptualization of LEADER, conceiving the creation of trans-national projects as the "highest" level of implementation in the EU regulation from the start (ENRD, 2010). By networking with LEADER groups from other countries, new ideas and methods should find their way into the work of the LAGs. Overall, however, in all member countries (and in all previous periods) the proportion of these trans-national LEADER projects fell short of what was desired (Dax and Kah, 2017). Trans-regional, and particularly trans-national cooperation was seen as a special opportunity to rethink the conventional action patterns and evaluation remit. Those LAGs that take part in such trans-national exchange projects do not learn so much from "groups of the same kind", but much more from dealing with other, different, approaches. These activities contribute in particular to the development of one's own identity and to an increased understanding of European references and regional differences.

Mirroring the scarce diffusion of trans-regional action, only very few studies on this aspect are available. The following reflections are based on the Italian survey of transnational cooperation (Fortunato and Zumpano, 2015), a dedicated exploration on a specific study of an Austrian LAG, focusing on cooperation conditions and potential incentives from such activities (Dax and Kah, 2017), and many years of experience of the LINC project, a "LEADER Inspired Network Community" extending currently to LAGs from already $17 \mathrm{EU}$ and non-EU countries (LINC, 2019), collaborating in the areas of regional development and cultural diversity, tangible through joint annual events with sporting activities and culinary focuses. These examples draw on communities of heightened commitment on this measure, enabling reflections on various trans-national cooperation projects. The focus on each of them is however different, underpinning the scope for action in trans-national cooperation. While the Italian investigation covers all national LAGs in their diverse projects, including linkages between LEADER LAGs and non-LEADER local activities, the study from an Austrian LAG highlights the results from involvement in three long-term trans-regional projects combining the cultural sphere with local development, and the third example flags a European network assembling interested LAGs from different Member States and beyond.

Analyzing implementation achievements through these good practice examples underscores that a wide range of value added can be provided through these trans-national cooperation (see Table 1). Important findings include the following:

- Reflecting one's own position is to a large extent based on exchange with other views and comparison with other cultures and approaches. Such exposure can enhance significantly self-assessment, evaluation learnings and contribute to extended development options for the region. 
- Local participation seems to be the key to shaping regional development and policy application of rural development programs. It seems important to build on existing knowledge and local commitment to utilize particular strengths, and relate local perspectives to an evidence-based survey of rural problems. Such an overview is tightly linked to and nurtured by trans-national activities.

- Other programmes, strategic approaches and good practice examples tend to be valued as instructive and achieve character of 'model' initiatives, but they should never be just transferred and "copied". In general, careful adaption is always required and might be the core of trans-national discussions.

- Since the spatial relationships can hardly be changed directly through individual measures, efforts in the politics of rural regions are shifting to long-term aspects such as quality of life and strengthening the attractiveness of the areas, social cohesion, networks and the transfer of knowledge (Copus and De Lima, 2015). Trans-national exchange is most effective when aware of historical legacies, context specificities, and institutional limitations.

- Long-term learning processes are often contradictory to immediate transfer lessons. Challenges attached to such demanding cooperative frameworks might constitute an insurmountable obstacle for many LAGs and lead to the low number of transnational cooperation across the EU (Pylkkänen et al., 2020). This raises questions why neither higher administrative units of national and regional actors nor local actors have put substantial efforts into action to overcome shortages in addressing cooperation potential and raising capacity at local level.

Table 1: Contribution of transnational projects to potential types of added value as defined by ENRD

\begin{tabular}{|c|c|c|c|}
\hline Added value of trans-national cooperation & $\begin{array}{c}\text { Italian assessment } \\
\text { of trans-national } \\
\text { cooperation }\end{array}$ & $\begin{array}{c}\text { Austrian } \\
\text { "Hard" added value } \\
\text { projects }\end{array}$ & $\begin{array}{c}\text { Experience } \\
\text { of LINC } \\
\text { cooperation }\end{array}$ \\
\hline $\begin{array}{c}\text { (1) Strengthening of territorial strategy and } \\
\text { local partnerships }\end{array}$ & ++ & ++ & + \\
\hline $\begin{array}{c}\text { (2) Realisation of more ambitious projects } \\
\text { through attaining critical mass }\end{array}$ & + & - & + \\
\hline $\begin{array}{c}\text { (3) Improving competitiveness: finding new } \\
\text { business partners and positioning on new } \\
\text { markets }\end{array}$ & - & - & - \\
\hline $\begin{array}{c}\text { (4) Strengthening local partnerships } \\
\text { (5) Shaping territorial identity and awareness }\end{array}$ & ++ & ++ & + \\
\hline $\begin{array}{c}\text { (6) New work practices and support of } \\
\text { innovation through new skills }\end{array}$ & ++ & ++ & - \\
\hline "Soft" added value & + & + & ++ \\
\hline $\begin{array}{c}\text { (7) Broadening mind-sets and realisation of } \\
\text { diversity in regions as a resource }\end{array}$ & ++ & ++ & + \\
\hline $\begin{array}{c}\text { (8) Developing European citizenship and } \\
\text { sense of identity }\end{array}$ & ++ & + \\
\hline \begin{tabular}{c} 
(9) Acquisition of new capacities \\
\hline
\end{tabular}
\end{tabular}

Note: medium impact (+), strong impact $(++)$.

Source: ENRD 2011, pp. 7-9; Dax and Kah, 2017, p. 220; Fortunato and Zumpano, 2018; LINC, 2019. 
By no means, the influence of trans-national cooperation should not be seen just through the financial contribution alone, which often remains rather restricted. For many LAGs, the impulse for new ideas from outside, the comparison and exchange with external partners and the open discussion of their own development approaches are often more decisive and an invaluable stimulus. These activities were carried out by many highlyengaged local administrative staff, regional managers, sector developers, including tourism experts, cultural and social group activists and local land managers and entrepreneurs. Spatially, there are very different and far-reaching collaborations, which are primarily characterized by network experience and practical aspects of cooperation. Although thematic and regional similarities are a criterion for practicable comparisons, institutional structures, processes and the willingness to exchange experiences and approaches are often more important for cooperation and learning capacity. The transnational cooperation activities analyzed for this paper extend the main dimensions envisaged through ENRD (2018), covering in particular the following contributions which are relevant for social innovation processes:

- They are characterized by specific "enthusiasm" of involved actors, appreciating new views on local economy, society and governance aspects. This aspect also conveys a new perception of European integration for the actors involved. Cooperation with more distant partners has to deal with specific obstacles such as language barriers, a different understanding of culture, different management approaches and governance frameworks, divergent participation experiences, as well as concepts of community and local cohesion, but simultaneously include a substantial degree of innovative incentives for many of these aspects.

- In the above-mentioned studies and in other exploration of trans-national cooperation (Pisani et Burighel, 2014; Navarro et al., 2018, 2020; Labianca et al., 2020) the reflection of internal approaches through exposure to other external concepts and imaginations is particularly pronounced. Such questioning of the own perceptions, procedures, goals, strategies and implementation processes might lead to reconsideration and new aspects to be incorporated, or revised approaches to be selected for future programs. Raising awareness of local actors is linked to knowledge development and transfer, and considered a crucial basis for strategic and socioeconomic development.

- Joint activities on numerous aspects of local action is enhanced, and quite often involves commercialization aspects, quality development, cross-sectoral cooperation, local food linkages etc.

- With technological changes marketing channels gain in relevance and application of new technologies become central, also in enabling swift access to consumers and urban places.

- In many respects, the uniqueness of LAG activities is a crucial issue: The focus is on local identity discourses, cultural heritage and building on specific local assets ("authenticity") as a means for shaping place-based strategies.

Trans-regional activities might thus assume very different tasks and priorities and analyses on specific outcomes, as presented in Table 1 provide some kind of stylized reflection on the learning processes. From these studies it can be concluded that territorial awareness and identity is strengthened, partnerships are extended, and regional diversity as well as European citizenship is promoted. These outcomes correspond to core objectives for trans-national activities in LEADER. In addition, the examination of the local culture, the specific landscape and its connection with the local land use as well as 
the understanding of the identity of the area and its communication in tourist activities, underline the effects of a far-reaching involvement of the local population for new forms of organization and solutions through these cooperation activities.

Since the 2014-2020 program period the objectives to address the specific local situation have been extended to Community-Led Local Development (CLLD) programs that enable, in addition to the EAFRD, financial support for local development programs by the EU's Structural Funds (ERDF, ESF, and EMFF) (Peters, 2013). While providing a promising policy framework for enhancing and coordinating local action, they were only taken up extensively in some of the countries or regions over this period (Servillo and De Bruijn, 2018). The increased territorial focus of these projects and the enhanced cooperation processes in the administration and among regional actors demonstrate the innovative power of this program development. It is particularly suitable for enabling trans-national projects and new forms of cooperation and can thus contribute to reinforce this aspect of regional strategy development and the effectiveness of activities (Pylkkänen et al., 2020).

\section{DIVERSITY AND SOCIAL INNOVATION AS DRIVERS FOR RURAL CHANGE}

The relevance of trans-national action within LEADER/CLLD is closely related to the endogeneity of strategic vision and governance arrangements. At the center of LEADER's remit is the understanding that joint and targeted efforts of local actors require external incentives as well to become and remain an inspirational resource for sensible place shaping (Celata and Coletti, 2015). Strategy development is therefore just one operational aspect which has to be complemented by involvement processes of actors and stakeholder groups in LEADER/CLLD decision-making and implementation. In this process, the various population groups, local companies, interest groups related to the region and public institutions deal with the specific problems and strengths of the region and can thus develop new options and corresponding regional strategies (Esparcia, 2014). Since these local development strategies have to take into account the scope of action of the respective rural development program, they are often bound to national specifications and administrative regulations. This can lead to LEADER's design options not being fully exploited, which might involve negative effects on the extent of innovation activities, or inducing uncertainty and reduced participation.

A comprehensive discussion of the LEADER concept with regard to the original priority for innovation led to a reorientation towards the original objectives at the beginning of the current period (2014-2020). The creation of "territorial capital" can be seen in a creative use of the various sub-areas, namely economic, social, cultural and natural capital. Decisive for long-term effective projects is not the "increase" of individual types of capital or the summation of the four capital areas, but the promotion of meaningful links between these areas in a creative, locally-specific assessment incorporating the needs of the local population (Figure 2). In the basic concept, LEADER emphasized a balanced view pooling together forces targeted at the various "types of capital". Addressing the social dimension in this web of basic capitals for local life is presented not just central in LEADER/CLLD, but also crucial in current discourse of "place-based policy" frameworks. Advocates for comprehensive place-based policies warn that "(p)olicies that ignore the emotion of economic change and job loss in the name of impartiality and rationality effectively turn their back on the dynamics through which 
individual lives are lived and societies are made. Emotions are fundamental to meaning and identity; they are central to one's experience of identity and place" (Beer et al., 2020, p. 19).

Figure 2: Central role of social innovation in local development

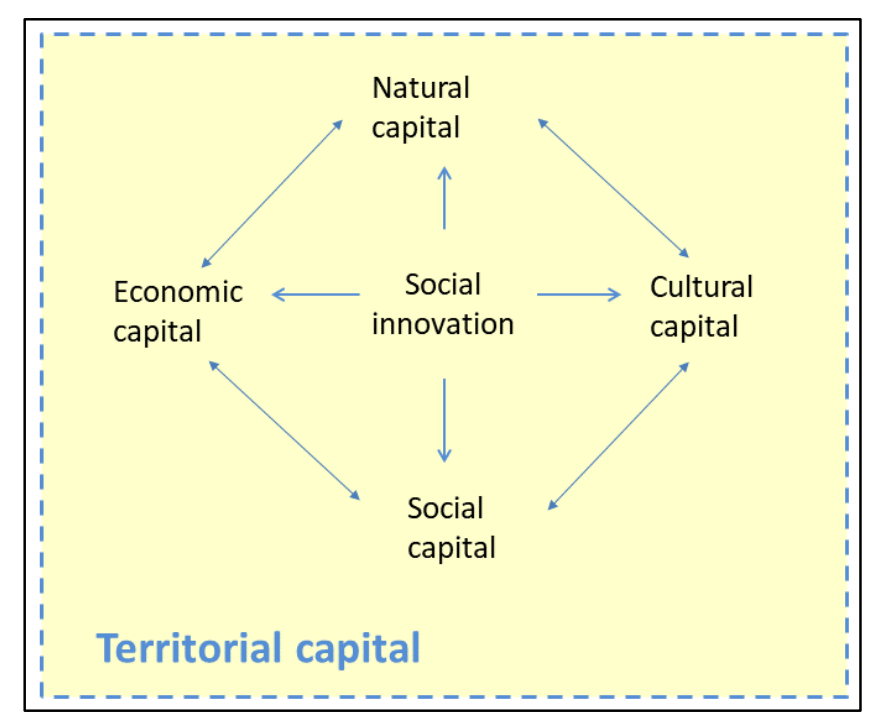

Source: own elaboration; based on Bourdieu, 1986, and Costanza and Daly, 1992.

As local development programs specifically seek to achieve sustainable trajectories encompassing effective changes in social relations, economy and natural resources, social innovation is pivotal to provide basics for these complex, inter-related and long-term processes. Local development action is intent on supporting and encouraging innovation as a means of developing "socio-economic systems and seek[ing] to meet unmet public needs and to create public value where markets and common socio-economic policies have failed" (Bock, 2012, p. 59). Indeed, expedient activities in rural development are dependent on the elaboration of new forms of organisation in institutional settings (Rodríguez-Pose, 2013) and at personal scale which result in social changes. The focus is hence on social innovations which "can be generally understood as a change in the attitudes, behaviour or perceptions of a group of people joined in a network of aligned interests that, in relation to the groups 'horizon of experiences, leads to new and improved ways of collaborative action in the group and beyond" (Neumeier, 2012, p. 65). Acknowledging the crucial role of diversity in this process of social change is at the basis of securing high participation levels and advancing horizontal and vertical, as well as trans-regional cooperation.

Such ambitious objectives refer to the task of thriving for accessing the local assets and building policy action on "endogenous resources" and potential. As revealed through the account of the long-term legacy of LEADER commitment across European rural regions, decisive incentives are nurtured by trans-regional exchange and the exposure to alternative perceptions and procedural strategies. Issues of participation of "all" sections of the population in the creation of the local development strategies are essential to avoid exclusionary tendencies or usurpation by specific social groups and views. The search for integration of all groups of different ages, genders, origins, nationalities, etc. is therefore a prerequisite for making social diversity visible in rural areas and achieve effective action at local level (Fidlschuster et al., 2016). Although these principles were emphasized again 
and again in the conception of LEADER, their implementation seemed protracted and fraught with difficulties in politics. Local policies were reduced to "optimizing" socioeconomic measures and limited success was referred to regulatory standards and (unavoidable) administrative obstacles (Dax et al., 2016). In the current programming period a turn towards prioritizing strategic accountability and effectiveness of public goods provision resulted in a sensible "rethink" of conceptual approaches towards emphasizing place-based needs of social groups (Dax and Oedl-Wieser, 2016).

Unfortunately, this is only lately reflected in the evaluation framework for LEADER/CLLD. So far, the focus of the evaluation questions of the CMEF have been on the general assessment of area and people addressed and jobs provided through the program measures. From the above it follows that the analysis of the process of social innovation should be a main task of evaluation of RDPs, particularly for local development measures (Dax et al., 2014). While it is referred to in evaluation questions of the CMEF to some extent, this hardly penetrates to the decisive questions. Experiences in carrying out evaluation studies suggest that reporting formats are often not conducive to allow intensive analysis and involvement of local participants in the evaluation process. As "enabling" rural development cannot be achieved by standard approaches or general advices won't be sufficient for instigating actually "enabling" environments and contexts where participation, cooperation, trans-regional exchange, "learning" process and inclusion is a core value and indicator for the program's success (Shucksmith, 2018), including aspects of territorial balance as referred to in recent discourse on 'spatial justice' (Shucksmith et al., 2020). Assessment would have to build on an in-depth involvement for each different case highlighting the place-specific design, application and results (Midmore et al., 2010). There is, however, the tendency to relate the inherent assessment deficiencies to methodological problems. Some of these flaws are addressed in national evaluation studies (Asamer et al., 2014) dealing with specific issues of the participation process within Leader, others dealing with cooperation (Zeuli and Cropp, 2004; Pfefferkorn et al., 2010). The crucial task should focus on how an increased involvement of local actors would impact on awareness and local capacity to address core aspects of place-sensitive social innovation processes.

\section{CONCLUSION}

Despite decades of continuous support for small-scale rural development through the LEADER concept and recent extensions to CLLD programs, many rural regions are still characterized by massive socio-economic challenges and processes of peripheralization. These find expression in weak economic performance, hardships in accessibility of services and ensuing persistent out-migration of large swathes of population, a situation similar to a "vicious cycle' captured in the expression of "shrinking rural regions" (Copus et al., 2020, in this volume). On the one hand, policies do not seem to provide appropriate answers to these challenges or fall short of expectations; on the other hand, the theoretical foundations and concepts are one-sidedly geared towards agglomeration areas and quantitative economic growth. This so far unquestioned paradigm has been considerably shaken by the COVID-19 pandemic in 2020, raising interest for alternative approaches for local development. In this sphere of rising tensions of socio-economic development prospects for different spaces and social groups, it is inevitable that no "approximation" of living conditions can be achieved without fundamental changes in policy design and 
inclusion of socio-economic layers, and more adapted processes (Moulaert and MacCallum, 2019).

Right from the start, LEADER placed the needs of the local population at the center of its "program philosophy". Thus, raising awareness of the "endogenous" opportunities and development paths, but also of the structural difficulties and obstacles, attains decisive importance. To integrate this concern in RDPs is a long-standing mantra of scholarly studies, stakeholder demands and societal expectation, but far from standard implementation practices. A step-change towards raising the priority of respective instruments and policy design would, however, only become possible with a reorientation of the value structure of the local population and strategic focus of programs on social innovation needs. This would imply a conceptual shift towards a comprehensive system of objectives for inclusive sustainable development. Innovation is therefore not any more a matter of creating "new products" or realizing increased technological efficiency, but rather recognizing the demand for altered social processes. This crucially touches upon issues of who defines needs, and whose situation is targeted at, as well to what extent inclusionary practice can be realized. The process of social innovation is since long a core task of the LEADER program which, however, has been side-lined whenever attention slides away or short-term efficiency considerations gain priority over social integration. With increasing social, economic, cultural, ecological and health challenges there is momentum to strengthen the implementation of these perspectives and deepen the social dimension through a conscious alignment in the program design of local development programs. The central role of fine geographical granularity of spatial differences for local development programs suggest particular commitment for placesensitive policy processes. Strong local identity and a strategic view building on endogenous assets can be an important driver for effective spatial policy and social change in rural regions.

As revealed through the emphasis on trans-regional action in this paper local discourses would gain from openness to the outside world, i.e. exchange and cooperation with other regions, countries, including different cultural backgrounds. This inter-relation is largely supportive on broadening views and perspectives, and might provide relevant incentives for enlarging and strengthening skill patterns, institutional processes and governance arrangements. From the participation in trans-national projects the following important aspects for success in stimulating social innovation processes could be derived:

- New pathways for local development are only found, if innovative processes are enabled. Spheres of experimentation are therefore crucial to explore new ideas, discuss alternatives, and test innovative but risky local initiatives. The creative design of social innovation processes could be decisively enhanced by trans-national cooperation activities.

- Participation of the various social groups at the local level in community actions is key to bring about social change, reflecting place-sensitive strategies and orientation at societal needs.

- Raising awareness and local capacities was a long-standing priority for endogenous, and neo-endogenous development. A thorough assessment on the prime deficiencies in local structures, systemic patterns forestalling enhanced community capacities and main obstacles for overcoming these lock-in challenges seem a fundamental prerequisite for unravelling major limitations for local development.

- The actors in administration and politics would not see their only priority in organizational issues to provide smooth structures and multi-level governance 
processes to implement programs and local action, but should develop the skills and strategies to support local initiatives of social innovation and to integrate these in their work portfolio. Such commitment is supported and inspired by trans-national cooperation.

Social innovation is a general social task and basis to acknowledging relevance of technological change and place-specific impacts. Indeed, it is particularly imperative whenever important societal changes accelerate and where spatial and social differentiation call for action to "close" striking socio-economic gaps. The orientation towards local conditions, the development opportunities and the design requirements of rural regions are thus becoming a priority for society as a whole. These priorities are not only important for small-scale rural development, but also relate to fundamental aspects of spatial and social cohesion. They are also part of a pan-European strategy to strengthen social innovation in order to ensure European values and equal living conditions in Europe's rural regions (Social Innovation Community, 2018). Thus, they relate to longterm social goals and effects. These can be read from the changes in terms of distributive justice, social 'participation' and equal opportunities in life, the forms and acceptance of coexistence, the recognition of social diversity and an increased reliance on "trust" as a building block for place-sensitive local policy action. In this way, the LEADER/CLLD concept and effective implementation patterns has the potential to draw on trans-national cooperation as an instrument to create decisive stimulus for innovative local development and to strengthen the attractiveness of rural regions.

\section{REFERENCES}

Asamer-Handler, M., Fischer, M., Lukesch, R., et al. (2014). Ausma $\beta$ und Wirkung von Beteiligungsprozessen in Lokalen Aktionsgruppen (LAG) 2007-2013: Final report. ÖAR.

Beer, A., McKenzie, F., Blažek, J., Sotarauta, M., and Ayres, S. (2020). Every place matters: towards effective place-based policy. Regional Studies Policy Impact Books, Vol. 2 No.1. Regional Studies Association. Taylor\&Francis.

Bock, B. (2012). Social innovation and sustainability; how to disentangle the buzzword and its application in the field of agriculture and rural development. Studies in Agricultural Economics, (114), 57-63. http://dx.doi.org/10.7896/j.1209

Bryden, J.M. (2010). Local Development. Chapter 23. In K. Hart, J. L. Laville, and D. Cattani (eds.), The Human Economy, A Citizen's Guide, (pp. 248-260). Polity Press.

Cejudo, E., and Navarro, F. (eds.). (2020). Neoendogenous Development in European Rural Areas. Springer Geography. Springer.

Celata, F., and Coletti, R. (2015). Place-based strategies or territorial cooperation? Regional development in transnational perspective in Italy. Local Economy: The Journal of the Local Economy Policy Unit, 29(4-5), 394-411. https://doi.org/10.1177/0269094214533903

Champetier, Y. (2017). LEADER Back to the future. 25 years of LEADER. AEIDL, Brussels. Retrieved from: https://www.aeidl.eu/images/stories/pdf/leaderyvesen.pdf $(26 / 05 / 2021)$. 
Copus, A. K., and De Lima, P. (eds.). (2015). Territorial Cohesion in Rural Europe. The Relational Turn in Rural Development. Regions and Cities 76. Routledge.

Copus, A., Kahila, P., Dax, T., Kovács, K., Tagai, G., Weber, R., Grunfelder, J., Meredith, D., Ortega-Reig, M., Piras, S., Löfving, L., Moodie, J., Fritsch, M., and Ferrandis, A. (2021). European shrinking rural areas: Key messages for a refreshed long-term vision. TERRA Revista de Desarollo Local (this volume).

Costanza, R., and Daly, H. E. (1992). Natural Capital and Sustainable Development. Conservation Biology, 6(1), 37-46. https://doi.org/10.1046/j.15231739.1992.610037.x

Da Rosa Pires, A., Pertoldi, M., Edwards, J., and Hegyi, F. B. (2014). Smart specialisation and innovation in rural areas, JRC Technical Reports, S3 Policy Brief Series No., 09/2014. Publications Office of the European Union. Retrieved from: https://publications.jrc.ec.europa.eu/repository/bitstream/JRC90000/jrc90000_poli cy\%20brief_n_092014\%20(2).pdf (26/05/2021).

Dargan, L., and Shucksmith, M. (2008). LEADER and Innovation. Sociologia Ruralis, 48(3), 274-291. http://dx.doi.org/10.1111/j.1467-9523.2008.00463.x

Dax, T. (2015). Why are Local Initiatives So Important in Mountain Regions? Mountain Views, Chronicles of the Consortium for Integrated Climate Research in Western Mountains. CIRMOUNT, 9(2), 44-46. Retrieved from: http://www.fs.fed.us/psw/cirmount/publications/pdf/Mtn_Views_dec_15.pdf

Dax, T. (2019). Development of mountainous regions: smart specialization approaches as a means to overcoming peripheralization. In I. Kristensen, A. Dubois, and J. Teräs (eds.), Strategic Approaches to Regional Development, Smart Experimentation in Less-Favoured Regions, (pp.52-67). Series Regions and Cities. Routledge.

Dax, T., and Copus, A. (2020). Final Report-Annex 13 How to achieve a transformation framework for Shrinking Rural Regions. European Shrinking Rural Areas: Challenges, Actions and Perspectives for Territorial Governance, ESPON 2020 project ESCAPE. Version 13/10/2020. ESPON EGTC. Retrieved from: https://www.espon.eu/sites/default/files/attachments/ESPON\%20ESCAPE\%20Fin al\%20Report\%20Annex\%2013\%20-\%20Transformation\%20Framework.pdf $(26 / 05 / 2021)$.

Dax, T., and Kah, S. (2017). Transnational Cooperation - an Opportunity for Social Innovation of Rural Regions. Special Issue on Territorial Cooperation. European Structural and Investment Funds Journal, (EStIF) 5(3), 211-222. Retrieved from: https://estif.lexxion.eu/article/ESTIF/2017/3/6

Dax, T., and Oedl-Wieser, T. (2016). Rural innovation activities as a means for changing development perspectives - An assessment of more than two decades of promoting LEADER initiatives across the European Union. Studies in Agricultural Economics 118(1), 30-37. http://dx.doi.org/10.7896/j.1535

Dax, T., Oedl-Wieser, T., and Strahl-Naderer, W. (2014). Altering the Evaluation Design for Rural Policies. European Structural and Investment Funds Journal (EStIF), 2(2), 141-152. Retrieved from: https://estif.lexxion.eu/article/estif/2014/2/10

Dax, T., Strahl, W., Kirwan, J., and Maye, D. (2016). The Leader programme 2007-2013: Enabling or disabling social innovation and neo-endogenous development? Insights 
from Austria and Ireland. European Urban and Regional Studies, 23(1), 56-68. https://doi.org/10.1177/0969776413490425

De Toni, A., Di Martino, P., and Dax, T. (2020). Location matters. Are science and policy arenas facing the Inner Peripheries challenges in EU? Land Use Policy 100, 105111. Published online 2 October 2020. https://doi.org/10.1016/j.landusepol.2020.105111.

Donald, B., and Gray, M. (2019). The double crisis: in what sense a regional problem? Regional Studies, 53(2), 297-308. https://doi.org/10.1080/00343404.2018.1490014

Esparcia, J. (2014). Innovative and networks in rural areas. An analysis from European innovative projects. Journal of Rural Studies, (34), 1-14. https://doi.org/10.1016/j.jrurstud.2013.12.004

European Commission - EC (2006). The LEADER approach: a basic guide. Brussels. Retrieved from: https://enrd.ec.europa.eu/sites/enrd/files/2B953E0A-9045-21988B09-ED2F3D2CCED3.pdf (26/05/2021).

European Network for Rural Development - ENRD (2011). LEADER Transnational Cooperation Guid. Brussels.

European Network for Rural Development - ENRD (2018). LEADER LAG Survey 2017, Findings at European Level. Brussels. Retrieved from: https://enrd.ec.europa.eu/sites/enrd/files/leader-resources_lag_survey_results.pdf (26/05/2021).

Fidlschuster, L, Dax, T.. and Oedl-Wieser, T. (2016). Demografischer Wandel, Diversität und Entwicklungsfähigkeit ländlicher Regionen. In R. Egger, and A. Posch (eds.), Lebensentwürfe im ländlichen Raum, (pp. 7-16). Springer Fachmedien.

Fortunato, A., and Zumpano, C. (eds.) (2015). Co-operation between rural areas: Leader and extra-Leader projects of Italian LAGs, Rete Rurale Nazionale 2007-2013, Roma.

Granberg, L., Andersson, K., and Kovách I. (eds.) (2014). Evaluating the European Approach to Rural Development, Grass-roots Experiences of the LEADER Programme. Perspectives on Rural Policy and Planning. Ashgate.

Green, D. (2016). How change happens. Oxfam and Oxford University Press: Oxford. Retrieved from: https://library.oapen.org/bitstream/id/a2d96f5a-5189-4cf8-a876d44eda71545f/618650.pdf (26/05/2021).

Harrison, J., Delgado, M., Derudder, B., Anguelovski, I., Montero, S., Bailey, D., and De Propris, L. (2020). Pushing regional studies beyond its borders. Regional Studies, 54(1), 129-139. https://doi.org/10.1080/00343404.2019.1672146.

Kasabov, E. (ed.). (2014). Rural Cooperation in Europe, in Search of the "Relational Rurals". Palgrave Macmillan.

Katona-Kovács, J., High, H.n and Nemes, G. (2011). Importance of Animation Actions in the Operation of Hungarian Local Action Groups. European Countryside, 3(4), 227-240. https://doi.org/10.2478/v10091-012-0006-7

Kull, M. (2014). European Integration and Rural Development. Ashgate.

Labianca, M., De Rubertis, S., Belliggiano, A., Salento, A., and Navarro, F. (2020). Social innovation, territorial capital and LEADER experiences in Andalusia (Spain) and 
in Molise (Italy). In E. Cejudo, and F. Navarro (eds.), Neoendogenous development in European rural areas. Results and lessons, (pp. 111-132). Springer Edit.

LEADER Inspired Network Community - LINC (2021). LINC conference 2021, 14-17 September, LAG Šumperský venkov, Czech Republic. Retrieved from: https://www.linc2021.eu/(26/05/2021).

Lowe, P., Phillipson, J., Proctor, A., and Gkartzios, M. (2019). Expertise in rural development: A conceptual and empirical analysis. World Development, (116), 2837. https://doi.org/10.1016/j.worlddev.2018.12.005

Lukesch, R. (2018). LEADER Reloaded. Keynote paper at the ELARD conference, 2628th September, Evora (PT). Retrieved from: https://leaderconference.minhaterra.pt/ (26/05/2021).

Lukesch, R., Bontron, J. C., Ricci, C., and Tödtling-Schönhofer, H. (2004). Methods for and Success of Mainstreaming Leader Innovations and approach into Rural Development Programmes. Final Report. ÖIR-Managementdienste GmbH.

Lukesch, R., Fidlschuster, L., Fischer, M., Said, N., Ecker, B., Gassler, H., Mair, S., and Philipp, S. (2019). Analyse der Potenziale Sozialer Innovation im Rahmen von LEADER 2014-20 (SILEA), Endbericht. ÖAR and ZSI. Retrieved from: https://www.oear.at/wp-

content/uploads/2019/05/Endbericht_SILEA_04_2019.pdf (26/05/2021).

Martin, R., Sunley, P., and Tyler, P. (2015). Local growth evolutions: recession, resilience and recovery. Cambridge Journal of Regions, Economy and Society, (8), 141-148. https://doi.org/10.1093/cjres/rsv012

Midmore, P., Partridge, M. D., Olfert, M. R., and Ali, K. (2010). The Evaluation of Rural Development Policy: Macro and Micro Perspectives. Eurochoices, 9(1), 24-29. https://doi.org/10.1111/j.1746-692X.2010.00155.x

Moulaert, F., and MacCallum, D. (2019). Advanced Introduction to Social Innovation. Edward Elgar Publishing.

Navarro, F. A., Woods, M., and Cejudo, E. (2015). The LEADER Initiative has been a Victim of Its Own Success. The Decline of the Bottom-Up Approach in Rural Development Programmes. The Cases of Wales and Andalusia. Sociologia Ruralis, 56(2), 270-288. http://dx.doi.org/10.1111/soru.12079

Navarro, F., Labianca, M., Cejudo, E., De Rubertis, S., Salento, A., Maroto, J. C. and Belliggiano, A. (2018). Interpretations of innovation in rural development, social innovation? The cases of LEADER projects in Lecce (Italy) and Granada (Spain) in 2007-2013 period. European Countryside, 10(1), 107-126. https://doi.org/10.2478/euco-2018-000

Navarro-Valverde, F. A., Pylkänen, P., Hyyryläinen, T., and Cejudo-García, E. (2020). Transnational Inter-Territorial Cooperation in the LEADER Approach. The Cases of Finland and Spain. Revista De Estudios Andaluces, (39), 114-133. https://dx.doi.org/10.12795/rea.2020.i39.06

Neumeier, S. (2012). Why do Social Innovations in Rural Development Matter and Should They be Considered More Seriously in Rural Development Research? Proposal for a Stronger Focus on Social Innovations in Rural Development Research. Sociologia Ruralis, 52(1), 48-69. https://doi.org/10.1111/j.14679523.2011.00553.x 
OECD (ed.) (2014). Innovation and Modernising the Rural Economy, OECD publishing, Paris. Retrieved from: http://dx.doi.org/10.1787/9789264205390-en (26/05/2021).

Ogilvy, S., and Costanza, R. (2015). Accounting for Ecological Capital. Ecology. DOI: 10.1093/obo/9780199830060-0106 (26/05/2021).

Peters, R. (2013). Investing in Europe's Future at Grassroots Level: The Role of EU Funded Community Led Local Development (CLLD). European Structural and Investment Funds Journal (EStIF) 1(1), 27-30. Retrieved from: https://estif.lexxion.eu/article/ESTIF/2013/1/4

Pfefferkorn, W., Leitgeb-Zach, M., and Favry, E. (2010). Kooperation in der ländlichen Entwicklung: Erfolgsfaktoren und Stolpersteine. Studie im Zusammenhang mit der Evaluierung des Leader-Schwerpunktes im Österreichischen Programm für die Entwicklung des Ländlichen Raumes 2007-2013. Rosinak und Partner.

Pike, A., Rodríguez-Pose, A., and Tomaney, J. (2006). Local and regional development. Routledge.

Pisani, E., and Burighel, L. (2014). Structures and dynamics of transnational cooperation networks: evidence based on Local Action Groups in the Veneto Region, Italy. Biobased and Applied Economics, 3(3), 249-269. https://doi.org/10.13128/BAE-14681

Pylkkänen, P., Hyyryläinen, T., and Navarro, F. (2020). Transnational cooperation-the underutilized potential of the European LEADER method. In E. Cejudo, and F. Navarro (eds.), Neoendogenous development in European rural areas. Results and lessons, (pp. 133-148). Springer Edit.

Ray, C. (2006). Neo-endogenous rural development in the EU. In P. Cloke, T. Marsden, and P. Mooney (eds.), Handbook of Rural Studies, (pp. 278-291). Sage Publications.

Rodríguez-Pose, A. (2013). Do institutions matter for regional development? Regional Studies, 47(7), 1034-1047. https://doi.org/10.1080/00343404.2012.748978

Servillo, L., and De Bruijn, M. (2018). From LEADER to CLLD: The Adoption of the New Fund Opportunities and of Their Local Development Options. European Structural and Investment Funds Journal (EStIF), 6(3), 223-233. Retrieved from: https://estif.lexxion.eu/article/ESTIF/2018/3/5.

Shucksmith, M. (2018). Re-imagining the rural: From rural idyll to Good Countryside. Journal of Rural Studies, (59), 163-172. https://doi.org/10.1016/j.jrurstud.2016.07.019

Shucksmith, M., Brooks, E., and Madanipour, A. (2020). LEADER and Spatial Justice. Sociologia Ruralis, (published online 29 December 2020). https://doi.org/10.1111/soru.12334

Social Innovation Community (2018). The Lisbon Declaration. Social Innovation as a Path to a Sustainable, Resilient and Inclusive Europe (H2020-project, Grant No. 69388). Retrieved from: https://ldnet.eu/wp-content/uploads/bsk-pdfmanager/Lisbon_Social_Innovation_Declaration_2018_47.pdf (26/05/2021).

Stöhr, W. (1984). Selective Self-Reliance and Endogenous Regional development Preconditions and Constraints. IIR-Discussion Papers, 19. WU Vienna University of Economics and Business. 
Torre, A., Corsi, S., Steiner, M., Wallet, F., and Westlund, H. (eds.) (2020). Smart Development for Rural Areas. Routledge. https://doi.org/10.4324/9780429354670

Visvizi, A., Lytras, M. D., and Mudri, G. (eds.) (2019). Smart Villages in the EU and Beyond (pp. 1-12). Emerald Publishing Limited. Retrieved from: https://doi.org/10.1108/978-1-78769-845-120191002

Zapf, W. (1994). Über soziale Innovationen. In W. Zapf (ed.), Modernisierung, Wohlfahrtsentwicklung und Transformation: soziologische Aufsätze 1987 bis1994, (pp. 23-40). Edition Sigma.

Zeuli, K. A., and Cropp, R. (2004). Cooperatives: Principles and practices in the 21st century. University of Wisconsin. Retrieved from: https://www.mcdc.coop/wpcontent/uploads/2020/01/Cooperatives-Principles-and-practices-in-the-21stcentury.pdf (26/05/2021). 